\title{
Student Assessment of Lecturers: A Strategy for Combating Corrupt Practices among University Teachers in Nigeria
}

\author{
Professor MKPA AGU MKPA \\ Faculty of Education, \\ Abia State University \\ Uturu-Nigeria
}

\begin{abstract}
It is common knowledge that corrupt practices among lecturers in most tertiary institutions in Nigeria exist in varied and diverse forms and magnitudes. This is very disturbing to stakeholders in the education industry.
\end{abstract}

This case study sought to determine if the innovative strategy of undergraduate students openly assessing and reporting on their lecturers' professional and moral behavior would result in improved disciplined behavior and reduced corrupt practices on the part of the lecturers. The study took place at Abia State University, Uturu, Nigeria and the subjects were all the 382 academic staff of the university. The data collection instrument was a structured and validated ten-item questionnaire that elicited information on a lecturer's teaching, leadership and moral behavior. Guidelines for the completion of the questionnaire were clearly established such that students assessed only lecturers in their department who taught and interacted with them regularly and so they are able to assess them objectively. The Center for Quality Assurance established specifically for this purpose undertook the university-wide data collection under my leadership as Vice-Chancellor Data were collected across two academic sessions. Results showed that the moment the university senate made up of senior academic staff, heads of department, deans of faculties and directors of academic units was informed of this innovation, all the university lecturers sat up and began to reduce if not stop those unwholesome behavior in order not to be rated poorly by students. Obtained data were used to classified lecturers under six categories of overall performance namely: "Distinction Ratings", "Very High Rating", "High Rating", "Average Rating", "Below Average Rating" and "Woeful Rating". The ratings over the two consecutive years of the assessment revealed a remarkably positive improvement on both the academic, leadership and moral behavior of the lecturers. Most of the acts of corrupt practices automatically disappeared from among the lecturers. In the second year of the rating exercise, more lecturers moved into the bracket of "Distinction Rating" while the percentage of those in the "Woeful Rating" reduced. The strategy is recommended to other Nigeria tertiary institutions since it proved successful.
Keywords:- Assessment, Lecturers, Corrupt practices, Universities.

\section{INTRODUCTION}

When, at various times, Nigeria was announced as one of the most corrupt countries in the world, one would expect that the university system should be largely insulated from the contaminating virus of corruption, given the pristine ideals which universities are expected to espouse.(Lawal, 2006; Galtima 2012; Kanno 2004). Other opinions would argue that since the University teachers are products of the larger Nigerian society, they could not escape the infestation of corruption. This later view is unfortunately true of the system. (Eze, 2006; Okogie, 2012).

Corrupt practices in Education refer to all forms of actions that reflect the perversion of established and/or expected standards or norms by those in authority in the educational system for their personal gains to the detriment of others and the system in its pursuit of quality manpower and national development. It includes all forms of irregularities taking place in the academia and which have direct negative impact on the expected quality and standard of education (Hillak and Poisson, 2007; Akinyemi 2004; Garner 2013; Ezeani 2005, and Ajan aku, 2006)

More specifically, corrupt practices especially among lecturers or academic staff include absenteeism from lectures, financial exploitation of students through forced and exorbitant sale of reading materials, sexual harassment of female students by their male teachers, compelling students to fund lecturers' social programmes such as wedding or burial ceremonies, sale of grades for money, leakage of examination question papers to female students in exchange for sex and/or money, giving students' examination scripts to fellow students to mark, deliberately failing or marking down students who failed to purchase a lecture's compulsorily sold reading materials; intimidating female students who resist a lecturer's amorous overtures, delay in submitting students' examination results, setting questions from topics not taught by the lecturer, failure to teach students all topics in the course outline; lecturers going into lecture and teaching for a few minutes and telling useless stories for the rest of the lecture periods etc. (Alutu \& Alutu, 2006; Okoye 2006; Porres 2016; Owen, 2001) 
The consequences of these and other corrupt practices on our educational system are terrible. They include: inability of Nigerian graduates to compete effectively with their foreign counterparts at international levels, difficulty for Nigerian graduates to secure admissions into post graduate programmes abroad (Douglas \& Chinyere 2017), loss of public confidence in the ability of Nigerian graduates to deliver reasonable goods and services in their fields of specialization-be they in medicine, engineering, law and other aspects of human endeavors. Pius, Ohawale and Kayde (2011) illustrate these instances of poor work output by reference to patients who die in the hands of poorly trained doctors, clients who lose their cases in court on account of poor professional handling by improperly trained lawyers, buildings and bridges that collapse on account of poor engineering capacity, insecurity challenges that continue to prevail even when supposedly trained security personnel are deployed, inability of our economists to find enduring solution to the nation's economic challenges, politicians who are unable to provide purposeful leadership in the country. These are result of corruption in the education system.

A pertinent question arises as to why the corrupt practices have been allowed to thrive for so long in our tertiary institutions. It is my opinion, as a former Vicechancellor that many chief executives lack the moral courage to address the issue frontally. They want to retain the friendship and support of as many academic staff as possible and so, they tend to gloss over those corrupt activities through which the staff generates extra funds. This is more likely so in situations where staff salaries are not paid by the governments as and when due. The academic staff would argue that when their salaries are owed for upward of two, three or more months, how would they survive if not to shift the burden to their students?

While this argument sounds logically reasonable, the idea is morally objectionable, atrocious, abominable and disgusting, to say the least. Furthermore, many lecturers, believing that they are "untouchables" and that they have the students' academic destinies in their hands think that nobody can challenge them in their corrupt practices. This should be regarded as a stillborn idea because any institution's chief executive must not tolerate this magnitude of professional rascality. Of course, every administrative head should know that duties can be delegated but responsibility cannot. This simply means that every Vice-Chancellor must be held responsible for the failure of staff under him/her just as he/she takes credit for the achievements of his staff. Heads of institutions should therefore not gloss over acts of professional misconduct of their staff otherwise they would be seen as incompetent, irresponsible and indeed unfit for the job of institutional leadership.

Given the entrenched culture of corrupt practices in the Nigerian university system and my resolve to make a significant and enduring difference in Abia State University, Uturu, Nigeria, it was a great challenge about how to strike a comfortable balance between retaining the confidence, support and professional interest of the lecturers on the one hand, and achieving a completely corruption- free academic environment. The university senate - the highest administrative and policy making organ of the university on matters of teaching and learning, was a key structure to be convinced about the strategy which I believed was going to be effective, which was getting students to assess their lecturers anonymously along the criteria for teacher effectiveness, and decent professional conduct. The result of the assessment was to be published so that each teacher/lecturer gets to know what students think about him/her. The best performing lecturers were to be celebrated in public while the poorly rated ones were to undergo planned counseling sessions for remediation.

\section{$>$ The Problem}

The problem which this study sought to address, put in a question form was: will the strategy of students assessment of their lecturers actually lead to a reduction, if not complete eradication of corrupt practices among the lecturers? Put differently: if students are given the opportunity to assess and comment on the professional conduct, attitude to work and general disposition of their learners, they, doing so anonymously and their verdict on the lecturers are published for the university community to see, will it result in a reduction of corrupt practices among the lecturers more so if the consequences of any poor rating will be detrimental to the career of the lecturer?

\section{$>$ Research Question}

The study was guided by one research question, namely: "To what extent will the strategy of student assessment of their lecturers produce a positive change in the academic, professional and moral conduct of the lecturers in Abia State University, Uturu, Nigeria?"

\section{METHODOLOGY}

The design of this is a case study. A case study is an in-depth study/investigation of a relatively small group or unit with a view to examining thoroughly all aspect of the group or unit. In this case, our small group or unit is only one university in the south-east of Nigeria, called Abia State University, Uturu. The university, founded in 1981 had a total of nine academic facilities and several departments. There were 382 Academic staff/lecturers and about 20,000 students in the various faculties and departments at the time of the study.

\section{$>$ Instrument}

The data collection instrument was a 10-item structured questionnaire which had 3 sections. The first section was for the personal data of the respondent which solicited information on the department and faculty of the student, name of lecturer being assessed and date. The student's name was not required because we believed that anonymity would allow the student the freedom and confidence to express his/her candid opinion about a lecturer without fear of victimization by the lecturer being assessed. The second section of the instrument sought the 
student's opinion on the professional competence of the lecturer being assessed in terms of ability to assist and guide students in knowledge discovery; and in classroom leadership. The third section elicited information on the lecturer's integrity, moral conduct in relation to the students and the extent to which he/she is involved in the corrupt practices listed above. The first five questions were on the lecturer's professional competence and the next five on integrity.

The last section of the instrument allowed the students an open-ended opportunity to express their general opinion on the lecturer's total personality - strengths, weaknesses.

Students responded to each of the questionnaire items on a four point-scale of Strongly Agree - (4 points) Agree (3 points) Disagree (2 points) and Strongly Disagree (1 point). By this scale, the maximum points a lecturer could score was $\underline{40}$ while the minimum was $\underline{10}$. In order to situate the lectures into appropriate classes of proficiency, we agreed thus:

\section{$38-40$ Points = Distinction Rating (DR) \\ $35-37$ Points $=$ Very High Rating $($ VHR $)$ \\ $30-34$ Points = High Rating $($ HR) \\ $25-29$ Points = Average Rating (AR) \\ $20-24$ Points $=$ Below Average Rating $($ BAR $)$ \\ $10-19$ Points = Woeful Rating $($ WR $)$}

The instrument was developed by a team of specialists in measurement and evaluation, and sociological foundations of education. It was validated by senior academic colleagues in the Faculty of Education and across some departments in the university. In the end, the instrument was certified to be valid for the purpose it was meant to serve. The test rested approach was used to establish the reliability of the instrument as it was administered to twenty students in a different university and they were to rate/assess any lecturer of their choice twice within an interval of 3 weeks. When the two sets of ratings were analyzed, The Pearson Product Moment Correlation Coefficient index of 0.88 was obtained, which figure was considered high enough for our purpose.

\section{Guidelines for Student Assessment:}

In order to guarantee objectivity of the assessment procedure, we established the following guidelines:

- Students must assess only the lecturers in their departments who have taught them for up to a semester. This is to ensure that the students were very familiar with the lecturer and would not be guessing about any response on him/her. No student was allowed to assess any lecturer who had not taught him or her at all.

- All students were encouraged to assess all the academic staff that had taught them in the course of the semester or in previous semesters. Heads of Department were encouraged to mobilize their students to undertake the assessment exercise.

- The need for objectivity was stressed among the students prior to the assessment exercise. Students were requested to be as objective as possible since the result of the exercise was going to serve the needs and interests of the students.

- Lecturers were not permitted to enter the hall or classroom while the student assessment was in progress. This was meant to avoid any undue influence on the students. The data were thus collected by the staff of the Center for Quality Assurance of the university.

- As observed above, anonymity was key to the success of the exercise. As a result, students were not to write their names or matriculation numbers on the questionnaire. With this proviso, students felt glad to express themselves as freely and confidently as possible without fear or inhibition.

\section{$>$ Assumptions}

The study was predicted on some basic assumptions:

- Students wear the shoes; they know where they pinch. They are in the best position to narrate how their lecturers behave in and out of the classroom professionally and regarding moral integrity. The lecturers can hardly testify negatively against themselves. As a result, the students' testimony about lecturers is more likely to be more credible than that of the lecturers.

- If lecturers know:

$\checkmark$ that they are going to be assessed by the students anonymously (and they cannot know what each student said/rated about them);

$\checkmark$ that the report of the students' assessment would be made public; and

$\checkmark$ that the report may determine their career prospects, popularity and relationship with the university authorities, they are likely to minimize if not completely stop their acts of professional misconduct. They would not risk the attendant stigmatization. If found "guilty" by the students' assessment.

\section{$>$ Data Collection.}

The Director, Centre for Quality Assurance of the University put out announcements on dates for visiting each faculty and its departments for the purpose of data collection. Heads of Departments ensured that as many students as possible were available to complete the questionnaire. The students were served copies of the questionnaire in their classrooms/halls and they were allowed ample time to complete their responses after which the questionnaire was retrieved. When all the students had completed the questionnaire, the Center for Quality Assurance conducted the data analysis using percentages.

The data were collected over two academic sessions. Each year, the students conducted the assessment and data were collected and analyzed. The data collected over the two years were analyzed and compared to see if there was an improvement in the professional conduct and integrity of the academic staff of the university. In other words, the data were to reveal whether the strategy of student assessment of their lecturers led to a reduction in the magnitude or incidence of corrupt practices in the institution. 


\section{RESULTS}

Research Question:

To what extent will the strategy of students assessing their lecturers reduce the incidence of corrupt practices among lecturers in Abia State University?
The Results of Student Assessment

The Center for Quality Assurance conducted and supervised the student assessment exercise over two consecutive years (2007/2008 and 2008/2009)

The analysis of the responses to the questionnaire is presented below as reported by the Director of the Centre. (Onwuka, 2010 in Mkpa 2010)

\begin{tabular}{|c|c|c|c|c|c|c|c|}
\hline Faculty & DR & VHR & HR & $\mathbf{A R}$ & $\overline{\text { BAR }}$ & WR & $\begin{array}{c}\text { NO. of } \\
\text { Lecturers }\end{array}$ \\
\hline Business & $2(5.71 \%)$ & $8(22.86 \%)$ & $21(60 \%)$ & $1(2.86 \%)$ & $2(5.71 \%)$ & $1(2.86 \%)$ & 35 \\
\hline Basic Med. Sc & 3(30\%) & Nil & $6(60 \%)$ & Nil & $1(10 \%)$ & Nil & 10 \\
\hline Education & 3(8.11\%) & $13(35.13 \%)$ & $14(37.84 \%)$ & $4(10.81 \%)$ & $3(8.11 \%)$ & Nil & 37 \\
\hline Environmental & $4(5.56 \%)$ & $25(34.72 \%)$ & $22(30.56 \%)$ & $10(13.89 \%)$ & $6(8.33 \%)$ & $5(6.94 \%)$ & 72 \\
\hline Law & $2(7.69 \%)$ & $11(42.31 \%)$ & $9(34.62 \%)$ & $2(7.69 \%)$ & $2(7.69 \%)$ & Nil & 26 \\
\hline MJC & $7(7.37 \%)$ & $19(20.00 \%)$ & $38(40.00 \%)$ & $24(25.26 \%)$ & $7(7.37 \%)$ & Nil & 95 \\
\hline Agric & $5(16.67 \%)$ & $13(43.33 \%)$ & $10(33.33 \%)$ & $2(6.67 \%)$ & Nil & Nil & 30 \\
\hline Physical/Bio & $6(10.35 \%)$ & $18(31.04 \%)$ & $24(41.388 \%)$ & $6(10.34 \%)$ & $3(5.17 \%)$ & $1(1.72 \%)$ & 58 \\
\hline Health Sciences & $1(5.26 \%)$ & $8(42.11 \%)$ & $6(31.58 \%)$ & $3(15.79 \%)$ & $1(5.26 \%)$ & Nil & 19 \\
\hline Total & $33(8.64 \%)$ & $115(30.10 \%)$ & $150(39.27 \%)$ & $52(13.62 \%)$ & $25(6.54 \%)$ & $7(1.83 \%)$ & 382 \\
\hline
\end{tabular}

Table 1:- Number and Percentage of Lecturers with Various Ratings by Student Assessment in 2007/2008

The exercise was repeated in the 2008/2009 academic session and the summary of the outcomes is presented below:

Table 2:- Number and Percentage of Lecturers with Various Ratings by Student Assessment in 2008/2009

A comparison of the performance of the lecturers in the two academic sessions is presented in table 3 below.

\begin{tabular}{|c|c|c|c|c|c|c|c|}
\hline Faculty & DR & VHR & HR & $\mathbf{A R}$ & BAR & WR & Total \\
\hline Business & Nil & $10(31.25 \%)$ & $15(46.88 \%)$ & $7(21.87 \%)$ & Nil & Nil & 32 \\
\hline Basic Med. Sc & $1(9.09 \%)$ & $3(27.27 \%)$ & $4(36.37 \%)$ & $3(27.27 \%)$ & Nil & Nil & 11 \\
\hline Education & $5(14.29 \%)$ & $7(20.00 \%)$ & $18(51.43 \%)$ & $2(5.71 \%)$ & $1(2.86 \%)$ & $2(5.71 \%)$ & 35 \\
\hline Environmental & $5(8.33 \%)$ & $26(43.33 \%)$ & $16(26.67 \%)$ & $11(18.33 \%)$ & $1(1.67 \%)$ & $1(1.67 \%)$ & 60 \\
\hline Law & $3(14.29 \%)$ & $2(9.52 \%)$ & $13(61.91 \%)$ & $2(9.52 \%)$ & $1(4.6 \%)$ & Nil & 21 \\
\hline MJCEFHSS & $11(12.09 \%)$ & $21(23.08 \%)$ & $36(39.56 \%)$ & $18(19.78 \%)$ & $5(5.49 \%)$ & Nil & 91 \\
\hline Agriculture & $3(12.00 \%)$ & $12(48.00 \%)$ & $7(28.00 \%)$ & $3(12.00 \%)$ & Nil & Nil & 25 \\
\hline Physical / Bio & $5(9.09 \%)$ & $15(27.27 \%)$ & $19(34.55 \%)$ & $15(27.27 \%)$ & $1(1.82 \%)$ & Nil & 25 \\
\hline Health Sc. & $2(13.33 \%)$ & $7(46.67 \%)$ & $4(26.67 \%)$ & $2(13.33 \%)$ & Nil & Nil & 15 \\
\hline Clinical Med. & $11(47.83 \%)$ & $8(34.78 \%)$ & $3(13.04 \%)$ & $1(4.35 \%)$ & Nil & Nil & 23 \\
\hline Total & $46(12.04 \%)$ & $111(29.77 \%)$ & $135(35.79 \%)$ & $64(16.73 \%)$ & $9(2.67 \%)$ & $3(1.00 \%)$ & 368 \\
\hline
\end{tabular}

- No of Lecturers in Percentage

\begin{tabular}{|c|c|c|}
\hline Rating & $\mathbf{2 0 0 7 / 2 0 0 8}$ & $\mathbf{2 0 0 8 / 2 0 0 9}$ \\
\hline Distinction & $\mathbf{8 . 6 4}$ & $\mathbf{2 9 4}$ \\
\hline Very High & $\mathbf{3 0 . 1 0}$ & $\mathbf{3 5 . 7 9}$ \\
\hline High & $\mathbf{3 9 . 2 7}$ & $\mathbf{1 8 . 7 3}$ \\
\hline Average & $\mathbf{1 3 . 6 2}$ & $\mathbf{2 . 6 7}$ \\
\hline Below Average & $\mathbf{6 . 5 4}$ & $\mathbf{1 . 0 0}$ \\
\hline Woeful & $\mathbf{1 . 8 3}$ & $\mathbf{1 0 0 . 0 0}$ \\
\hline Total & $\mathbf{1 0 0 . 0 0}$ & \\
\hline
\end{tabular}

Table 3:- Comparative Performance of Lecturers in the 2007/2008 and 2008/2009 sessions' Assessment in Percentage. 
A careful examination of the figure in table 3 reveals that in the 2008/2009 academic session, there was an increase in the percentage of staff that belonged to Distinction Rating category from $8.64 \%$ to $12.04 \%$, and a decrease in the percentage of woeful rating from 1.83 to 1.00. This simply implies that more lectures become more conscious of their professional mandate, related better and more responsibly with students, and demonstrated greater integrity than in the previous academic session. There was also a significant improvement (reduction) in the percentage of staff who belonged to the "Below Average". Whereas in the previous academic session $6.54 \%$ had "Below Average rating, the following year, this figure was reduced to $2.67 \%$. The strategy can therefore be said to have succeeded in reducing the rate of corrupt practices among the lecturers.

\section{Consolidating the Gains of the Strategy}

In order to encourage more lecturers to steer away from those corrupt practices, we decided to apply the strategy of positive reinforcement. All those who emerged in the category of "Distinction Rating" were publicly celebrated. They received the Vice-Chancellor's award presented as plaques of excellence in a colourful ceremony witnessed by all staff and students of the university. The idea was to make as many lecturers as possible strive to win the prize in the subsequent rating exercise. For the lecturers to succeed in this, they would have to stop completely all those acts of professional irresponsibility since the students were to be frank in assessing them in the next assess. Furthermore, those with "Distinction Rating" and "Very High Rating" were to enjoy priority consideration in the appointment of Deans of Faculties and Heads of Departments as well as other important appointment in the university.

Those staff with "Below Average" and "Woeful Rating" - the worst in the rating scale, were reprimanded and they entered into an undertaking with the university to improve on their behavior or risk their continued membership of staff of the university. They were referred to the university counseling center for some remediation therapy.

The effect of this could be seen in the fact that the students felt liberated from the erstwhile near suffocating stranglehold of many of the lecturers. For fear of being graded poorly by students, the staff/lecturers began to demonstrate better and improved work ethics. They became more punctual and regular to classes, respected and interacted more responsibly with the students, taught their lectures more diligently and related more cordially with the students.

\section{DISCUSSION}

The result has shown that the strategy of lecturers being anonymously assessed by their students was very effective in stemming the tide of corrupt practices among teachers in Abia Sate University Uturu. It is reasonable to generalize this finding to all other tertiary institutions in Nigeria for the following reasons: In the first place, both staff and students in Nigerian tertiary institutions are drawn from one or similar socio-cultural pool. The economy of Nigeria is similar across the geo-political zones. Salary payments to lecturers are similar in frequency, quantity and quality. The Federal and State Universities share a lot in common in terms of quality of manpower, salary structure and modalities for payment. Private Universities are somewhat different in that they are not under the same kind of management as the state and federal institutions.

Secondly, the concept of academic freedom which the state and federal universities clamor for appears to encourage them to do whole lot of unethical things rather unchallenged even by the institution's authorities. When this idea is stretched beyond reasonable limits, the result is the kind of rot/high incidence of corrupt practices that prevails in our universities.

Thirdly, the trade unions in tertiary institutions - the Academic Staff Union of Universities, Non Academic Staff Unions, Senior Staff Association of Nigerian Universities, and National Association of Technical Teachers often tend to adopt a defensive posture in favour of their colleagues, even when such colleagues commit professional misconducts. The more powerful the trade unions, the more they tend to intimidate the leadership of the institutions because no leader wishes to be threatened with the most formidable weapon of the trade unions which is a strike action. The result is that many heads of tertiary institutions hesitate to go tough with erring academic staff. This fact explains even if only in part, why the private tertiary institutions ban trade unions as a matter of policy.

The section of the instrument that allowed students the opportunity to comment freely on their general impression of the lecturer was very revealing. Students were very blunt in detailing what each lecturer was in the habit of doing good or bad. They illustrated specific instances of acts of professional irresponsibility and even went on to recommend lecturers they wanted to be sacked from the university. Such information was very useful to the management of the university and the university counseling centre in handling the lecturers. These were largely those lecturers that received "Woeful" and "Below Average Rating". The information resulting from the assessment also helped and guided the university management in deciding on whom to appoint to head the departments and directorates. 
Going by the comments of the students, the most prominent of the corrupt practices among the lecturers had to do with sexual harassment of the female student by male lecturers, sale of grades for money, force purchase of reading materials and absenteeism (Nwaopara A, Ifenhor and Ohiwere (2008). Unfortunately these are very despicable corrupt practices that should not be seen to exist in any decent academic environment. It is our earnest hope and belief that if the strategy is implemented and sustained, there is bound to be a remarkable turn-around of the moral fortunes of the academic in the ivory towers. It remains for the Vice-Chancellors to muster the political will, courage and resolve to put into practice the strategy which has proved to be effective in curbing the corrupt propensities of the unscrupulous lecturers.

\section{A. Conclusion}

From available data on the results of the study, the strategy of students assessing their lecturers and commenting freely on their professional and integrity profiles has proved to be effective in curbing the incidence of corrupt practices among lecturers in Abia State University, Uturu. The strategy is likely to be effective not only in the university system but also in all other tertiary institutions in Nigeria since the same problem of corruption is known to exist in most of the institutions. If widely implemented across all the tertiary institution in Nigeria, we are likely to harvest an improved quality of tertiary education in the country. Since the quality of tertiary education in any country determines the quality of manpower development in the said country, this strategy has enormous potentials for improvement of the manpower and technological development in Nigeria (Garner, 2013; Akiyemi, 2004; Pius, Ohawale and Kayode 2011)

\section{B. Recommendation}

In the light of the discussions and conclusions above, it is hereby recommended that:

$>$ Heads of tertiary institutions in the country should resolve that definite steps must be taken to stamp out corrupt practices among the lecturers in their various institutions.

$>$ All tertiary institutions in the country should, as a matter of urgency understudy the Abia State University model and adopt or adapt it to suit their circumstances for the purpose of ensuring that the strategy is implemented.

$>$ Tertiary institutions in Nigeria should set up Quality Assurance Units where they do not exist and charge them with the responsibility of designing the strategies for adapting the Abia State University model in order to achieve excellence in curriculum delivery efforts by the lecturers.

$>$ Heads of tertiary institutions should cultivate the courage to deal harshly with lecturers who persistently engage in corrupt practices, who receive "Woeful" and "Below Average" ratings. This is to serve as a deterrent to potential culprits while encouraging those with "Distinction" and "Very High Ratings"

$>$ Tertiary institutions that do not yet have counseling centres should set up such centres which should be manned by competent personnel to offer remediation therapy to lecturers who need such services.

$>$ Payment of salaries to lecturers in our tertiary institutions should be regular at the end of each month so that unscrupulous lecturers will not have any excuses for engaging in corrupt practices

\section{REFERENCES}

[1]. Hallack, J \& Poisson, M (2007) Corrupt schools corrupt universities: What can be done?_Paris UNESCO Publishing.

[2]. Owen, W, (2001) Student attendance and absenteeism dropping out: How much do schools contribute to the problem? Teacher College Record 87(3), 374-392.

[3]. Pores, B.A (2016) The impact of teacher absenteeism on student achievement: A Study on the 2011-2012 civil rights data collection.

[4]. Ajanaku, J.B. (2006) Integrity and work out put in I.E. Nwosu and O.C. Eneh (Eds) Managing job ethics and productivity in Nigerian Universities. Enugu, Precision publishers Ltd.

[5]. Ezeani, E (2005) Education in Nigeria: Problems, Dilemmas and Perspectives London, Veritas Human publishers.

[6]. Garner, B.A (2013) Blacks Law Dictionary Texas, A Thormson Reuters Business.

[7]. Osipian, A.I. (2012) Education corruption, reform and growth: case of Post-Soviet-Russia. Journal of Eurasian Studies 3 (1) 20-29.

[8]. Nandap, J, Stephen, D.T.; Abdullah S.D. (2019) Corrupt practices: Threat to quality education in Nigeria. KIU Journal of Social Sciences 5 (1): $265-$ 273

[9]. Alutu, O.E. \& Alutu A.N (2008) Unethical practices among academics as perceived by undergraduates: A case study of the University of Benin. Journal of Counseling Association of Nigeria 23, 183-187

[10]. Eze, J.U. (2006) Counseling strategies against corrupt practices in universities. The Counselor. 23, 15-24

[11]. Galtima, M. (2012) Corruption has assumed a worrisome level. Vanguard www.vanguardngr.com. Retrieved Oct 2, 2012

[12]. Kanno, T.N. (2004) Changing values in Nigerian society and curriculum implications. In B.B. Oderinde \& Ekpo (Eds) Values Education lagos: Nigerian Academy of Education.

[13]. Lawal, A.A. (2006) Corruption in Nigeria: A Colonial legacy. Inaugural lecture Ibadan, University of Ibadan. Oyo press

[14]. Okojie, J. (2012) Corruption had assumed a worrisome level Vanguard. www.vanguardngr.com. Retrieved Oct. 2, 2012

[15]. Okoye, C.U. (2006) Need to review Nigeria's dying education Vanguard, www.vanguardngr.com. Retrieved Feb. 12, 2007.

[16]. Onwuka, J.O (2015) Quality Assurance in Mkpa, MA (Ed) My Leadership as Vice-Chancellor, Abia State University Uturu, 2005-2010, Uturu, Abia State University press. 